\title{
Turizmusbiztonság, mint újonnan felmerülő fogyasztói igény
}

\author{
Szerzők: Péter Erzsébet ${ }^{1}$ - Németh Kornél² - Lelkóné Tollár Ildikó
}

A turizmusban az elmúlt években rendkívül jelentôs változások történtek. A világban zajló események nemcsak a turisztikai szakembereket és az utazni vágyókat, hanem a rendfenntartó erôket is új kihívások elé állítják. Az általános rendôri feladatok mellett napjaink új rendészeti kihívásai közé tartozik a terrorveszély elhárítása turisztikai desztinációkban és kiemelt rendezvényeken. A szakmai nehézségek közé sorolható a vezényelt állomány helyismeretének hiánya, a helyszinre történó érkezés ideje, illetve a nagy tömegben történố megfigyelés, kommunikáció korlátai. A desztinációk biztonságáról kialakult kép meghatározza az utazási döntést, ugyanakkor a megváltozott utazási szokások mellett mégis egyre több az utazás. A tanulmány többek között arra keresi a választ, hogy a közelmúlt eseményei mennyire befolyásolják a pihenési szokásokat a turisztikai desztinációkban, illetve hogy egy-egy rendezvény helyszinen, valamint a médiában közölt hírek biztonságot vagy bizalmatlanságot ébresztenek-e az emberekben. A XXI. század emberének nagyon fontos a folyamatos újítások megléte az élet minden területén. A turisták számának és tartózkodásának növeléséhez „komplex élménycsomagot” kell kínálni, amely más típusú vállalkozásokkal való együttmüködést feltételez. Minden térségnek törekednie kell arra, hogy márkává váljon és a vendég olyan élményekkel távozzon, amikre jó visszaemlékezni, amik miatt szeretne visszatérni egy biztonságos környezetbe. A fogyasztókban felmerülő igény alapján az utazások és a helyszínválasztás meghatározó eleme lett napjainkban a biztonság.

Kulcsszavak: megújuló szolgáltatások, turizmusbiztonság, rendezvények.

\section{Bevezetés}

A turizmus alapvetôen bizalmi iparág, és komplex rendszerének egyik legfontosabb alapja a biztonság. A biztonság problematikája természetesen rendkívül sokrétú kérdésköröket vet fel a természeti katasztrófáktól, a pénzügyi folyamatokon, és a terrorizmuson át egészen a szálláshely-szolgáltatás, a környezet, az élelmiszerek, az egészség vagy a közlekedés biztonságáig. A turizmus rendszerében az utazási döntést befolyásoló tényezők, így egy desztináció meghatározó elemei a prekoncepció és a tapasztalat. Az előbbihez tartozik a politikai környezet, a közlekedés biztonsága (repterek, repülők, vonatok), a természeti környezet biztonsága (vízminőség, cunamik, vulkánkitörés) és a

\footnotetext{
1 egyetemi docens, Pannon Egyetem Nagykanizsai Kampusz, peter.erzsebet@uni-pen.hu

2 egyetemi docens, Pannon Egyetem Nagykanizsai Kampusz, nemeth.kornel@uni-pen.hu

3 mesteroktató, Pannon Egyetem Nagykanizsai Kampusz, tollar.ildiko@uni-pen.hu
}

határokon átívelő, senkit sem kímélő terrorizmus (WILK 2017). Az utazások során elsôsorban biztonságos desztinációt választunk, másodsorban érdeklődésünknek megfelelő szórakozási lehetőséget, illetve rendezvényhelyszínt. Egy rendezvény megszervezése során a szervezőnek rendkíviul körültekintően kell eljárnia. Több jogszabály hatálya is kiterjedhet egy adott rendezvényre attól függően, hogy azt építményben vagy szabad téren rendezik meg, illetőleg, hogy mekkora résztvevői létszámra számítanak a rendezvény során. Nem csak nagy létszámú, nagy területú rendezvények szervezőinek kell ismerni a vonatkozó előírásokat, hanem akár egy községi önkormányzat polgármesterének is, aki a szokásos falunapot vagy év végi mulatságot szervezi meg (KIRÁLY - VÁJÓ 2015). Egy turistákat és helyieket egyaránt vonzó rendezvény védelme érdekében a rendőrség korábban az esemény körül külső és belső, azaz kettős biztosítást végzett. A külső, tágabb biztosítást a rendészeti osztályok, a közlekedésrendészet és a közrendvédelem látja el. A biztosított terület a rendezvényen kívüli utcákat foglalja magában, melynek alapvetô célja egy külsố szúrô kialakítása a rendezvényt zavaró magatartások, továbbá a búncselekmények 
megakadályozása, megelőzése (gépjármú feltörések) érdekében. Ellenőrzó-átengedő pontokat hoznak létre, hogy minél biztonságosabban és kényelmesebben tudják a helyszínt védeni, és a tömeget kezelni. A belső biztosítás is kiemelt jelentőséggel bír, ami azt jelenti, hogy egy népszerú turisztikai desztinációban megrendezésre kerüló, akár nemzetközi, rendezvény/fesztivál vagy sportesemény vonatkozásában a behajtás a kiszolgáló, a szervezók kényelmét biztosító autók és buszok számára is meg van tiltva. A világ turizmusában az elmúlt években rendkívül jelentős változások történtek. Mára a turizmus biztonsága meghatározó jelentőségú prioritássá vált. A turizmus biztonságát veszélyeztetô tényezők nagy mértékben erősítik a kulturális sokk lehetséges kialakulását (MALOTA - MITEV 2013, BOGÁROMI - MALOTA 2017). A biztonságot azonban egy nemzet sem tudja önmagában garantálni, hosszú távon csak a regionális és nemzetközi együttmúködés tud stabilitást hozni (KELLER 2004).

\section{Módszertan}

Érdeklődésünk fókuszába a Zala megyei aktív munkavállalók kerültek, mivel a diszkrecionális jövedelmük magasabb a többi társadalmi csoporténál, és a biztonságos desztinációk kiemelt prioritást élveznek utazási helyszíneik kiválasztásakor.

A kvantitatív kutatáson belül kérdőíves Omnibuszkutatás készült. A mintasokaság 508 fó volt, amelynek $49 \%$-a volt férfi és $51 \%$-a nó. A felmérés nemenként volt reprezentatív a Zala megyében dolgozó aktív munkavállalók körében. A mintába kerülés során az „Egyszerú Véletlen Kiválasztás Módszerét" választottuk. Az összefüggés vizsgálat során korrelációt számoltunk, melynél figyelembe vettük a Pearson féle korrelációs együttható társadalomtudományokban elfogadott szignifikancia szint melletti értékét (MOLNÁR 2015, BARNA et al. 2006).

\section{Trendek és változások a pihenési szokásokban}

A nem túl biztonságos helyeken csak a védett, „,all inclusive" vakációfalvak tudnak túlélni, és a posztmodern turizmus számos formája lehetetlenné válik ezeken a helyszíneken. A pihenésre szánt idó a munkáltató befolyása, illetve a saját magunkkal szembeni elvárások miatt rövidül. A folyamatos pörgés nemcsak kimerültséghez, rosszabb esetben kiégéshez vezethet, hanem sajnos tartósan fennálló betegségekhez is. Nem csak a zalai, hanem a magyar lakosság nagy részére is jellemző, hogy gyorsan, sokat szeretne pihenni. Igénye lenne a változásra, de anyagi okok vagy belső késztetés miatt nemet mond rá. Ezzel ellentétes trendként jelenik meg többek között az úgynevezett "lassú" turizmus" (ERNSZT 2016a, ERNSZT - LŐRINCZ 2017). A fogyasztói/turisztikai trendnek megfelelóen az élménymarketing az utazás során is fontossá válik, a helyi alapanyagokat felhasználó helyi konyha megismerésének vágya akár fó motivációként, akár az utazás elmaradhatatlan részeként is jelentkezhet. Az utazó arra vágyik, hogy amikor visszanézi egy fotón a pihenés pillanatait, jó élmény kerítse hatalmába, és egyre fontosabbá válik, hogy úgy érezze érzelmileg is gazdagodott az út során. Azon desztinációk, amelyek biztonságos helyként élnek az utazók tudatában, javukra tudták fordítani a világ egyes országainak biztonságpolitikai helyzetében bekövetkezô változásokat, míg más desztinációk, melyek percepciója utazás szempontjából veszélyesnek bizonyult, számos turistát vesztettek. Ahogyan az a 2016-os évben megfigyelhető volt, annak ellenére, hogy a légi közlekedés az alacsony olajáraknak köszönhetóen relatíve olcsó maradt, és számos ország vezetett be utazóbarát vízumpolitikát, helyenként a terrorfenyegetettség a felsorolt pozitív tényezőknél nagyobb mértékben volt hatással a turizmus iparágára, ami miatt újra eljött a háttértelepülések és rejtett vidéki üdülőkörzetek ideje.

A MAGYAR TURISZTIKAI ÜGYNÖKSÉG (2017) jelentése szerint a terrorizmus által sújtott országokban - mint például Belgiumban, Franciaországban vagy Törökországban - a beutazó turisták száma és költése nagymértékben visszaesett. A kulturális, gasztronómiai fesztiválok, sportrendezvények kiváló eszközként szolgálnak a nemzeti értékek bemutatására a nagyközönség számára, mindezt egy olyan közegben, amely a résztvevők számára kikapcsolódást, szórakozást nyújt. A magas értéket képviseló rendezvények emellett nagymértékben hozzájárulhatnak a pozitív ország-kép kialakításához, a nemzeti identitás erósítéséhez.

Utazása során a turista jóllétének alapja a testi biztonsága és az egészsége. Ezen alapvetó tényezők mellett azonban a turista jólléte többet, valamiféle megelégedettséget, lelki egyensúlyt is feltételez. E vágyak természetesen nem maguktól jelennek meg a tudatukban. Az örömért való utazáshoz, a nyugalmat és biztonságot nyújtó otthon elhagyásához szükséges vágyakat egy rendkívül kifinomult rendszer élteti. A turista a legritkább esetben ismerheti meg a marketing által neki reklámozott lokális autentikusságot, kultúrát és életmódot. Ezen logika szerint a turista vágyai tulajdonképpen sosem teljesedhetnek be. Az autentikusság fogalmának konstruktivista és reflexív felfogása azonban meghaladja a valóság és a turista számára 
felkínált konstrukció közötti határt. Mindez nem szünteti meg a turizmusipar konstruáló, szelektáló és kanonizáló eljárásait, a helyi kultúrára gyakorolt hatását, azonban világossá teszi, hogy a turista elégedettsége nem feltétlenül ezektől függ (PUSZTAI 2013).

A kikapcsolódást kínáló rendezvények egyéb turisztikai termékhez kapcsolódva komplex kínálat létrehozását teszik lehetôvé a turisztikai szezon meghosszabbítására. Ami a fesztiválpiac európai trendjeit illeti, megállapítható, hogy 2017-ben a válság hatása még érezhetô, de összességében nő a piac. A nagy, többnapos fesztiválok válnak egyre népszerúbbé, és jellemző a rendezvények specializációja is. A legfontosabb és legmeghatározóbb trend e turisztikai termék kapcsán is az élményturizmus, és a rendezvényturizmusban is egyre inkább előtérbe kerül a desztináció megközelíthetősége, valamint kiemelt szerepet kapnak a biztonsági kérdések. Az utóbbi évtizedben a rendezvényturizmusban a területi koncentráció csökkenésének lehettünk tanúi: számos vidéki rendezvény, fesztivál erôsödött meg, melyek évrôl évre színvonalas programkínálatot biztosítanak látogatóik számára, és a szervezésük, marketingkommunikációjuk is folyamatosan fejlődik. Erôs állami szerepvállalás mellett számos nagy nemzetközi sportrendezvény is megrendezésre kerül hazánkban, részben a bizonyos sportágakban elért évszázados eredmények, részben a sport lobbi tevékenységnek köszönhetően (úszás, vízilabda, vívás, kézilabda, futball stb.). A sportrendezvények egyre több utazót vonzanak, évról évre dinamikusan emelkedik a sportesemény miatt útnak indulók száma (MAGYAR TURISZTIKAI ÜGYNÖKSÉG 2017).

A Tourist Police egy olyan különleges szolgálat a rendfenntartó szervek prevenciós munkájában, amelynek célja a búnesetek megelőzése, illetve segítségnyújtás a bajba került turisták számára. A turisztikai információk továbbításához a legtöbb Tourist Police szervezetnél megfelelő idegen nyelvú tolmácsolás áll rendelkezésre. A „Turista Rendőrség" munkájára legfőképpen az idegenforgalmilag leginkább látogatott régiókban van szükség, és általában a nyári főszezonban látják el a szolgálatot (OLÁH 2010).

2017-ben az utazók jelentős része döntött úgy a TURIZMUS ONLINE (2018) jelentése szerint, hogy felfedezi a világ kevésbé ismert részeit. A felmérés során megkérdezettek 45\%-a tervezett kalandosabb élményeket nyújtó úti célt választani, míg 47\%-uk szeretett volna olyan helyre eljutni, ahol még egyik ismerôse sem járt. Legyen szó egy elszigetelt hegyi faluba tartó túrázásról vagy bármilyen más, szokatlanabb élményről, az emberek egyre nagyobb kalandvággyal vágnak neki útjaiknak, hogy autentikus módon fedezzenek fel addig ismeretlen környékeket.

Bár a technológia egyre nagyobb teret nyer az élet minden területén, az utazás során kialakuló valódi emberi kapcsolatok és a vendégszerető személyzettel való interakció szintén felértékelődik. Ahogy például a mobiltelefonok és a közösségi média egyre inkább részeseivé válnak a magánszférának, úgy ezzel párhuzamosan a turisztikai szolgáltatók is több platformon képesek kapcsolatot tartani a fogyasztókkal (SIMAY - GÁTI 2017). Az empirikus kutatásunk eredményei szerint az emberek többsége nem szállna meg olyan helyen, ahol a személyzet barátságtalan és nem segítőkész, ugyanakkor a közvetlen kapcsolatra épító magánszálláshelyek népszerúsége töretlenül növekszik.

\section{A választást meghatározó tényezôk fogyasztôi szemmel}

Az empirikus kutatás eredményei között szerepel, hogy mik azok a motiváló tényezők, amelyek meghatározzák a munkavállalók döntéseit. Likert skálán kértük jelölni (ahol az 1 a legkevésbé jellemző, az 5 a leginkább jellemzố választást jelentette), milyen szempontokat mennyire tartanak fontosnak a vizsgálatba bevont személyek (1. táblázat).

A megkérdezettek meglehetôsen nagy hangsúlyt fektetnek a megfeleló ár/érték arányra (4-27,1\%; 5-62,4\%), de jelentős mértékú a biztonságérzet (4-25\%; 5-59,1\%) is, ami arra utal, hogy olyan desztinációkat, illetve helyeket keresnek az üdülni vágyók, ahol nem érzik magukat veszélyeztetve.

1. táblázat

\section{Az utazási döntést meghatározó fóbb tényezók (megoszlás)}

\begin{tabular}{|l|c|c|c|c|c|}
\hline & $\mathbf{1}$ & $\mathbf{2}$ & $\mathbf{3}$ & $\mathbf{4}$ & $\mathbf{5}$ \\
\hline Ár/érték arány & $0,6 \%$ & $1,0 \%$ & $8,8 \%$ & $27,1 \%$ & $62,4 \%$ \\
\hline Biztonság & $4,5 \%$ & $9,1 \%$ & $2,3 \%$ & $25,0 \%$ & $59,1 \%$ \\
\hline Minôség & $0,6 \%$ & $1,2 \%$ & $6,6 \%$ & $42,0 \%$ & $49,6 \%$ \\
\hline Étkezési lehetôség & $4,1 \%$ & $5,1 \%$ & $22,2 \%$ & $31,0 \%$ & $37,6 \%$ \\
\hline $\begin{array}{l}\text { Wellness } \\
\text { lehetôségek }\end{array}$ & $11,6 \%$ & $12,7 \%$ & $23,2 \%$ & $28,0 \%$ & $24,5 \%$ \\
\hline $\begin{array}{l}\text { Szolgáltatások } \\
\text { száma }\end{array}$ & $5,6 \%$ & $9,3 \%$ & $32,0 \%$ & $35,1 \%$ & $18,0 \%$ \\
\hline $\begin{array}{l}\text { Sportolási } \\
\text { lehetőségek }\end{array}$ & $12,1 \%$ & $18,9 \%$ & $31,2 \%$ & $24,7 \%$ & $13,1 \%$ \\
\hline
\end{tabular}

Forrás: saját szerkesztés 
A szükségletek hierarchiájában a fiziológiai szükségletek nyomában ott van rögtön a biztonság utáni vágy. A szervezett tömegturista kedveli az úgynevezett „all inclusive” (minden turisztikai szolgáltatást magába foglaló) utazási csomagokat, és keveset találkozik a helyiekkel, mert így a legkielégítőbb a pihenése és a biztonságérzete. Napjainkban már egyre jobban igaz a biztonság kiemelt szerepe a felfedezó turista típusára is, akinek korábban minimális biztonságra és kényelemre volt szüksége, utazását önállóan, egyénileg szervezi, és szívesen ismeri meg a helyi lakosokat, ugyanakkor szeretné mindezt nyugalomban tenni.

Saját vizsgálatunk eredménye szerint a megkérdezett zalai munkavállalók 39,2\%-a külföldön, míg $60,8 \%$-a belföldön nyaralt. A nyári pihenést $47,8 \%$ választotta, azonban ennek időtartama az eredmények szerint a korábbi 7-10 napról 5 napra szúkült. Az országos átlaghoz hasonlóan töretlen a hosszú hétvégék népszerúsége, ami átlagosan 3 napos üdülést jelent. A kutatásunk eredménye szerint a fogyasztók több mint 90\%-a használja az internetet utazási információk elérésére országosan. Az utazásszervezők és utazásközvetítők szinte mindegyike rendelkezik saját honlappal, ennek ellenére a szolgáltatók többsége mégsem ismeri a szolgáltatásukról online információt keresô, vagy szolgáltatásaikat igénybe vevó utasokat, ahogy nem használja a keresőoptimalizálást sem. Ez azt is jelenti, hogy sem online értékesítési tevékenységük tényleges hatékonyságáról, sem irodájuk online célcsoportjáról nem rendelkeznek megfelelő információval. Ennek elkerülése érdekében javasolni lehet a szolgáltatóknak a honlap látogatottság mérésének bevezetését, egy olyan webstatisztika kialakítását, melynek segítségével könnyen végezhetőek olyan felmérések, amelyekkel megállapíthatóak például, hogy kik és honnan (például keresők, desztinációs honlap) látogatják a weboldalt, hogy bizonyos időszak(ok)ban (hónap, év) hányan vettek igénybe alap (szállás, programok) vagy kiegészítő (biztosítás) turisztikai szolgáltatást (GYULAVÁRI - HUBERT 2014). Az utazásszervezó irodák ezen webstatisztikai eredmények felhasználásával megtudhatják továbbá, hogy a honlapjukat látogató fogyasztókat melyik menüpontok érdeklik a legjobban, ezáltal a legtöbbször "rákattintott” menüpontot a legszembetúnőbb helyre tudják helyezni a honlapon. Míg a fogyasztók többsége részéről megjelenik az igény, hogy mások véleményét is elolvassák a fórumokon utazás előtt, addig az utazási irodák közül csak néhány rendelkezik honlapján saját fórummal. A többi szolgáltató úgy érzi, nem érdekelt egy ilyen online szolgáltatás létrehozásában, amit azonban a fogyasztók hiányolnak (PÉTER et al. 2017). A GFK legfrissebb, 2017-es, nyaralási terveket vizsgáló
1000 fős, országos reprezentatív felmérésének adatai szerint a magyar lakosság kicsivel több mint fele (54\%) tervez utazást idén nyáron, közülük a legtöbben (32\%) belföldi úti célban gondolkodnak, 10\%-uk külföldre készül és 12\% bel- és külföldi utazást is beiktat a nyári szabadságába. A legnépszerúbb hazai úti cél továbbra is a Balaton, külföldön pedig a horvát, görög és olasz tengerpart, valamint Erdély. Az utazási szokások látványosan összefüggnek az életkorral, a társadalmi, anyagi helyzettel és a lakóhellyel. Míg a 20-29 évesek jellemzően külföldre utaznak, addig a 40-49 évesek szívesebben pihennek a határokon belül (GFK 2018).

A hosszú hétvégék népszerúsége töretlen (1. ábra), az országos átlaghoz hasonlóan 30,8 \%-os, ami átlagosan 3 napos üdülést jelent (PÉTER 2017). A nyári nyaralás 47,5 \%-kal vezet, azonban empirikus eredményeink szerint $4-5$ napra rövidült a korábbi évekhez képest.

\section{1. ábra}

A legnépszerúbb pihenésre szánt idôszakok megoszlása a válaszadók véleménye alapján

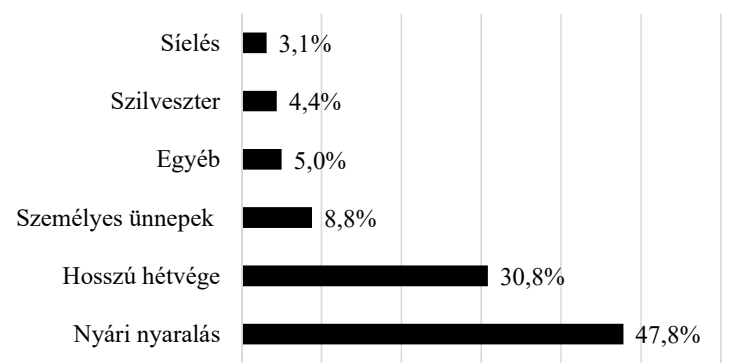

$\begin{array}{lllllll}0,0 \% & 10,0 \% & 20,0 \% & 30,0 \% & 40,0 \% & 50,0 \% & 60,0 \%\end{array}$

Forrás: saját szerkesztés

Érdekes a 20-29 éves Y-generáció választása: legtöbbjük ugyan európai utazást tervez, de nem a fenti „klasszikus" nyári desztinációkat célozza meg, hanem például Dániát, Írországot vagy Hollandiát. Tíz százalékuk a tengerentúlra utazik, a többiek pedig Észak-Afrikát, Azsiát vagy Ausztráliát célozzák meg (GFK 2018).

A kutatásunk eredménye szerint a fogyasztók több mint 90\%-a használja az internetet utazási információk elérésére országosan. Az utazásszervezők és utazásközvetítők szinte mindegyike rendelkezik saját honlappal, ennek ellenére a szolgáltatók többsége mégsem ismeri a szolgáltatásukról online információt kereső, vagy szolgáltatásaikat igénybe vevő utasokat, ahogy nem használja a keresőoptimalizálást sem. Ez azt is jelenti, hogy sem online értékesítési tevékenységük tényleges hatékonyságáról, sem irodájuk online célcsoportjáról nem rendelkeznek megfelelő információval. 
$\mathrm{Az}$ internetes hirdetés, illetve a fórumokon való tájékozódás ugyan nagy népszerúségnek örvend (2. ábra), azonban a látogatók olyan helyre szeretnek visszatérni, ahol már volt pozitív tapasztalatuk $(22,3 \%)$ vagy rokonaik, illetve barátaik ajánlották nekik $(25,8 \%)$. Emellett továbbra is nagyon sokat számít mások véleménye: az utazók többsége nem választana olyan szállást, amelyról háromnál több negatív véleményt olvasott (PÉTER 2017). Akik útra kelnek, azok egyre inkább kezdik megérteni, hogy az emberi kapcsolat pótolhatatlan, nyaralásukat pedig a közvetlen interakciókkal tennék még emlékezetesebbé.

\section{Választási szempontok megoszlása}

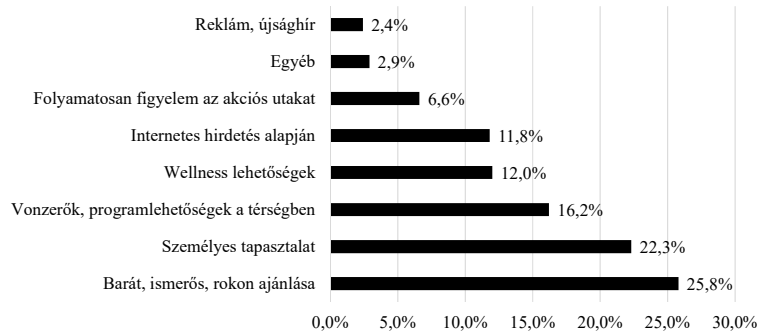

Forrás: saját szerkesztés

A biztonsági kérdésekhez kapcsolódó személyes tapasztalat mély nyomot hagy az utazókban, hiszen egyetlen mosoly elérheti, hogy visszatérjünk adott desztinációba, ugyanakkor egyetlen negatív élmény is elegendő ahhoz, hogy végérvényesen elutasítsuk a jövőben.

\section{Motivációs tényezók az utazási döntés} meghozatalakor

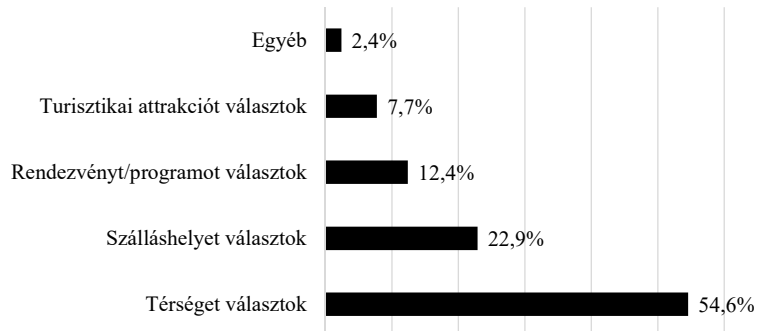

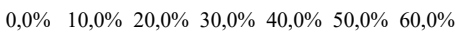

Forrás: saját szerkesztés

A sok turistát vonzó rendezvényeknek óriási a jelentôsége, hisz amennyiben a helyszínnek egyébként vonzó a turisztikai imázsa, nagyobb lesz az érdeklődés a turisztikai csomagok iránt is, így esetleg package értékesítésére is lehetőség nyílhat. Amennyiben a helyszín olyan, amelynek a turisztikai vonzereje nem elég erős, a visszatérô rendezvény emelheti iránta a látogatók érdeklődését, így a desztináció, ha lassan is, de fejlődni fog.

A legtöbb válaszadó turisztikai desztinációt választ $(54,6 \%)$, de a szálláshely $(22,9 \%)$ és a rendezvények/programok $(12,4 \%)$ is kiemelt fontosságúak egy-egy döntés meghozatalakor. Kiemelt prioritás a biztonság és az élménydús környezet, amire jó visszaemlékezni (3. ábra).

A Zalában vizsgált munkavállalóknak a wellness ma is gyakran jelenti azt, hogy amikor pihenni megy, sokat eszik és jókat alszik. Mivel „nem vesztegetheti az idejét", új élményekkel is gyarapodni szeretne $(15,1 \%)$ és keresi a kalandot $(6,9 \%)$, ami felejthetetlenné teheti a nyaralást, amire a válaszadók szerint szintén csak egy nyugodt és biztonságos környezetben van lehetőség.

Ahogy azt a 4. ábra is szemlélteti, a pihenés és a kikapcsolódás vágya erôs (33,2\%), ugyanakkor az elmúlt évekhez képest nôtt az új élmények keresése $(15,1 \%)$, csakúgy mint a kalandkeresés (6,2\%), ami a megkérdezett alanyok közül már az Y és Z generáció képviselőire jellemzô. Ôk bátrabban vágnak neki egy-egy utazásnak, akkor is, ha kevesebb diszkrecionális jövedelemmel rendelkeznek, és úgy érzik, velük soha nem történhet semmi baj.

\section{Célkitúzések megoszlása a nyaralás alkalmával}

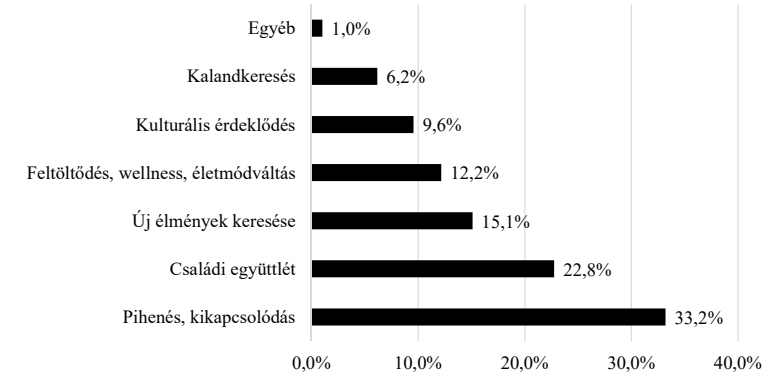

Forrás: saját szerkesztés

Ha a világ több pontján van fenyegetettség (legyen az belpolitikai vagy terrorfenyegetettség, esetleg gazdasági válság), az jelentős akadálya lehet a turizmus további fejlődésének, illetve sor kerülhet a turizmus jelentős területi átrendeződésére is, mivel a turisták el fogják kerülni a túl veszélyes helyeket. A 2011 során Észak-Afrikában és a Közel-Keleten bekövetkezett forradalmak nyomán ilyen változások máris megfigyelhetők voltak a turisztikai desztinációk földrajzi átrendeződése 
kapcsán. Hasonlóképpen, a környezeti problémák, a szennyezések és katasztrófák szintén befolyásolhatják a turizmus további fejlődését, és elriaszthatják a turistákat egyes helyszínekről vagy akár nagyobb régiókból is. Remélhetóleg azonban ezek a politikai és környezeti problémák nem fognak túl gyakran, túl sok helyen bekövetkezni, és ezáltal a vizsgálatban tárgyalt új turisztikai tendenciákat sem fogják túl nagymértékben visszavetni.

A növekvő terrorveszély és a külföldiekkel szembeni ellenszenv növekedése egyes kultúrákban befolyásolhatja a turizmust, mind mennyiségi, mind minőségi oldalról. Ahogy az 5. ábrán is látható, a megkérdezettek több mint fele (54,7\%) nem veszi figyelembe a terrorfenyegetettséget utazásai során, de mivel hazánkat biztonságosabbnak vélik, $22,4 \%$ dönt a belföldi nyaralás mellett és nem utazik külföldre.

\section{A terrorizmus hatása az üdülési szokásokra}

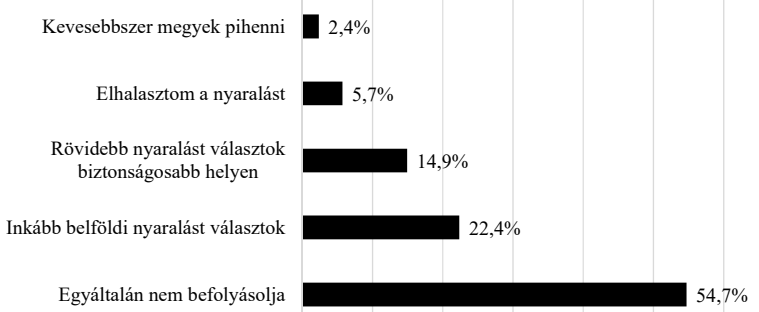

$\begin{array}{lllllll}0,0 \% & 10,0 \% & 20,0 \% & 30,0 \% & 40,0 \% & 50,0 \% & 60,0 \%\end{array}$

Forrás: saját szerkesztés

A nagy tömegeket megmozgató rendezvények vonatkozásában is elsődleges a biztonság kérdése. Magyarország szerencsére nem a terroristák támadásainak célpontja, azonban a biztonsági intézkedéseket illetően 2017. évben előzetes egyeztetés zajlott az állam részéről az Alkotmányvédelmi Hivatallal és a Terrorelhárítási Központtal, mint szakszervekkel, illetve a helyi önkormányzatokkal, tudtuk meg KERTÉSZ (2017) kapcsolódó eredményeiből.

Eredményeink alapján a válaszadók 75\%-ánál még nem fordult elő, hogy terrorfenyegetettség miatti félelemből mondott volna le valamilyen programot (2. táblázat), azonban 25\%-uk ütemezte már át az utazását úgy, hogy a korábban tervezett rendezvényre nem látogatott el. A leghosszabb idejú tartózkodást nemzetközi sportmérkőzések esetén figyelhettünk meg a turisták körében (11\%).

Ahogy Kovács Péter, a Magyar Labdarúgó Szövetség biztonsági igazgatóhelyettese nyilat- kozta, már a beléptetés biztonsága is több fázisból adódik össze (BIZTONSÁGPIAC ÉVKÖNYV 2017). Bár a folyamat a jegyvásárlásnál kezdődik, mégis a biztonsági kapu az, ami megállítja azokat a személyeket, akiket valamely sportszervezet már kizárt. Ezen felül, a stadionokban zárt láncú megfigyelő rendszer múködik, ami rögzíti a felvételeket. Az úgynevezett spotterek, vagy más néven rendőri megfigyelők, folyamatos kapcsolatot tartanak a szurkolókkal, és próbálnak információkat közvetíteni a rendőri vezetésnek a tömeg dinamikájáról és a várható negatív eseményekről.

2. táblázat

\section{Korábbi terrortámadások vagy terrorfenyegetettség miatt lemondott programok}

\begin{tabular}{|c|c|}
\hline Nem fordult elő & $75,0 \%$ \\
\hline Sport jellegú & $11,0 \%$ \\
\hline Komplex rendezvények & $6,0 \%$ \\
\hline Müvészeti jellegú & $4,7 \%$ \\
\hline Egyéb & $1,7 \%$ \\
\hline Kereskedelmi jellegú & $0,8 \%$ \\
\hline Közmúvelödési jellegú & $0,6 \%$ \\
\hline Társadalmi, politikai jellegúu & $0,2 \%$ \\
\hline Tudományos jellegúu & $0,0 \%$ \\
\hline Egyházi jellegúu & $0,0 \%$ \\
\hline
\end{tabular}

Forrás: saját szerkesztés

Az összefüggésvizsgálatok során korrelációszámítást végeztünk, ahol egy erős kapcsolat jött ki az utazási döntés és az életkor között. Az eredmény érdekessége, hogy a Pearson féle korrelációs együttható előjele negatív $(-0,718)$ volt 0,0007-es szignifikancia szint mellett. Ez egy ellentétes irányú kapcsolatot mutat, miszerint minél fiatalabb valaki, annál bátrabban hozza meg a döntését, melyet a pénzügyi helyzete sem befolyásol, mert pénz szúkében alternatív lehetőséget választva internetes fórumokon érdeklődik olcsó vagy ingyenes szállás iránt. Amikor a munkavállaló szervezete jelzi, hogy ideje pihenni, a fiatalok előbb ismerik fel a „veszélyt”. A középkorú és idősebb válaszadók maximum a gyorsan-sokat pihenést engedik meg maguknak, amely újabb kihívásokat jelent nemcsak az egészségügyben dolgozóknak, hanem a turisztikai szakembereknek is. 


\section{Következtetések}

A biztonságnak főszerep jut az utazási döntések meghozatalánál, amit empirikus kutatásunk is alátámasztott, és ami a jövőben még inkább felértékelődik. Az idegenforgalomban elsődleges szempont a rendőrség proaktív munkája, melynek célja, hogy a turistát hozzásegítse biztonságérzetének kialakításához. E feladatkör betöltéséhez szükséges a különböző turisztikai szervezetekkel, önkormányzatokkal való együttmúködés, illetve a végrehajtó szervek és a társadalom közti megfelelő kommunikáció, melyek együttes célja a búncselekmények számának csökkentése, a búnesetek áldozatainak segítése, továbbá a teljes körú tanácsadás (BUJDOSÓ - GYÖRKI 2011, ERNSZT 2016b).

Minden lehetséges médiában a biztonság hangsúlyozása a cél, és fontos, hogy folyamatosan tájékoztassák a külföldi partnereket és a belföldi fogyasztókat egyaránt. Az állam részéról a pánik megelőzésére a megfelelő diplomácia és konzuli szolgálat/külképviselet szerepel az első helyen. A Turisztikai Ügynökség részéről sokat számít a biztonságérzet kialakításában egy jól elkészített imázs film, valamint a megfelelő desztináció és event menedzsment (PÉTER 2017).

A személyes biztonság (közbiztonság, Tourist Police) mellett az utazni vágyók nagy hangsúlyt fektetnek a vagyontárgyaik biztonságára, valamint a pénzügyi biztonságukra. A desztináció biztonságára vonatkozó prekoncepciók erősen befolyásolják az utazási döntést. Felerôsödött a social media szerepe a prekoncepciók alakításában, és a megtapasztalt biztonság hírének terjesztésében.

A turista nem mond le az utazásról, csak más desztinációt választ. Magyarország és Budapest biztonságos desztinációk, azonban az utazási döntés pozitív befolyásolása érdekében ezt tudni kell megfelelően kommunikálni is a turisták felé (WILK 2017).

Az élménymárkázáshoz eszköz lehet egy jól elkészített weboldal, a public relations, prospektusok, kiadványok, ajándéktárgyak és egyéb márkázott termékek vagy online hirdetések, de a legfontosabb az elégedett vendég, amihez nélkülözhetetlen a megfelelő szervezeti struktúra és a biztonságos közeg biztosítása.

Az összefüggés vizsgálatokból kiderült, hogy a fiatalabb generációk tagjai bátrabban hoznak döntéseket (kevesebbet aggódnak a biztonság miatt), és a pénzügyi helyzetük sem feltétlenül befolyásolja döntéseiket. Mindkét nem esetén a választott térséget emelték ki fő motivációként a nyaralási döntés meghozatalánál. A vizsgálat alanyai abba a desztinációba térnek vissza, ahova valamilyen pozitív élmény köti ôket, ami akár érzelmi marketing propagandával is befolyásolható. Érdekes lehet itt felülvizsgálni a TDM szervezetek tevékenységét, ugyanis a turizmussal foglalkozó szakmai szervezeteknek húzó szerepet kell betölteniük, illetve a menedzsmentnek a turisztikai szuprastrukturák esetén is hatékonyan kell reagálni az új kihívásokra.

\section{Köszönetnyilvánítás}

A kutatás az Emberi Erőforrások Minisztériuma ÚNKP-17-4 kódszámú Új Nemzeti Kiválóság programjának támogatásával készült.

\section{Felhasznált irodalom}

BARNA K. - NAGY M. Z. - MOLNÁR T. (2006): Egyszerúen statisztika II. Perfekt Kiadó, Budapest.

BIZTONSÁGPIAC ÉVKÖNYV (2017): A focimeccs legyen családi program. Biztonságpiac.hu Kft.

BOGAROMI E. - MALOTA E. (2017): Kulturális sokk és fogyasztói akkulturáció - kétirányú, interdiszciplináris megközelítésben. Vezetéstudomány. 48(4). pp. 6-17.

BUJDOSÓ Z. - GYÖRKI M. (2011): A biztonság szerepe a turizmusfejlesztésben. Acta Carolus Robertus. 1(2). pp. 45-56.

ERNSZT I. - LÓRINCZ K. (2017): A lassú turizmus, mint termékfejlesztési irány - Kőszeg esettanulmánya. Comitatus Önkormányzati Szemle. 27(3). Különszám. pp. 54-59.

ERNSZT I. (2016a): Kőszeg slow turizmusban rejlő lehetôségei - A lassú filozófia. In: Miszlivetz F. (szerk.): Kisvárosok reneszánsza, A kőszegi példa. Savaria University Press - Felsóbbfokú Tanulmányok Intézete, Szombathely - Kőszeg.

ERNSZT I. (2016b): "Sullen Shadows Under the Blue Sky" - Some Remarks about the Dark Side of Tourism and the International Legal Protection. In: Németh K. (szerk): I. Turizmus és Biztonság Nemzetközi Tudományos Konferencia. Pannon Egyetem Nagykanizsai Kampusz. Tanulmánykötet. pp. 98-106.

GFK (2018): Balaton vagy Adria? http://www.origo. hu/utazas/hirek/20170620-a-lakohelytol-esaz-eletkortol-is-fugg-hova-utazik-valaki.html, Letöltve: 2018. február 14.

GYULAVÁRI T. - HUBERT J. (2014): A hatásosság és hatékonyság fogalmainak értelmezése online vs. offline kampányok keretében. In: Hetesi E. - Révész B. (szerk): "Marketing megújulás": Marketing Oktatók Klubja 20. Konferenciája. SZTE GTK, Szeged. pp. 302-310. 
KELLERK. (2004): Az újraegyesült Németország növekvő nemzetközi biztonságpolitikai szerepvállalása: a Bundeswehr „out-ofarea" bevetései. Külügyi Szemle. 3(3-4). pp. 186-219.

KERTÉSZ R: (2018): Önfeledt szórakozás biztosítása, egy kihívásokkal teli tömegrendezvényen. In: Kiglics N. (szerk): II. Turizmus és Biztonság Nemzetközi Tudományos Konferencia. Pannon Egyetem Nagykanizsai Kampusz. Tanulmánykötet. pp. 66-72.

KIRÁLY L. - VÁJÓ N. (2015): Rendezvények biztonsági kérdései. Hadmérnök. 10(1). pp. 11-23.

MAGYAR TURISZTIKAI ÜGYNÖKSÉG (2017): Nemzeti Turizmusfejlesztési Stratégia 2030. http:// www.kormany.hu/download/8/19/31000/mtu_ kiadvany_EPUB_297x210mm\%20-\%20preview. pdf, Letöltve: 2018. február 10.

MALOTA E. - MITEV A. (2013): Kultúrák találkozása. Nemzetközi kommunikáció, kultúrsokk, sztereotípiák. Alinea Kiadó, Budapest.

MOLNÁR T. (2015): Empirikus területi kutatások. Akadémiai Kiadó, Budapest.

OLÁH T. (2010): Turizmus és közbiztonság kapcsolata Salgótarján példáján. In: Bujdosó Z. - Györki M. (szerk): A biztonság szerepe a turizmusfejlesztésben. Acta Carolus Robertus. 1(2). pp. 45-56.

PÉTER E. (2017): Dilemma: Menni vagy maradni? Változó igények, átalakuló pihenési szokások. In: Kiglics N. (szerk): II. Turizmus és Biztonság Nemzetközi Tudományos Konferencia.
Pannon Egyetem Nagykanizsai Kampusz. Tanulmánykötet. pp. 219-225.

PÉTER, E. - KELLER, K. - NÉMETH, K. -LELKÓNÉ TOLLÁR, I. (2017): Integrating health literacy into work and relaxation. In: Kiglics N. (szerk): II. Turizmus és Biztonság Nemzetközi Tudományos Konferencia. Pannon Egyetem Nagykanizsai Kampusz. Tanulmánykötet. pp. 392-397.

PUSZTAI B. (2013): A turista jóllét forrása Találkozás az autentikus látnivalóval vagy igazi önmagunkkal. In: Michalkó G. - Rátz T. (szerk): Jó(l)lét és turizmus: utazók, termékek és desztinációk a boldogság és a boldogulás kontextusában. Kodolányi János Fóiskola, MTA CSFK Földrajztudományi Intézet, Magyar Földrajzi Társaság. Székesfehérvár-Budapest. pp. 13-21.

SIMAY A. - GÁTI M. (2017): A fogyasztói jelenlét és a nyilvánosság iránti attitúdök vizsgálata a mobil és közösségi médiában. Vezetéstudomány. 48(1). pp. 61-69.

TURIZMUS ONLINE (2018): 2017 legnagyobb utazási trendjei. http://turizmusonline.hu/ kulfold/cikk/2017_legnagyobb_utazasi_ trendjei, Letöltve: 2018. február 20.

WILK A. (2017): Magyarország, mint biztonságos desztináció - Biztonság és Turizmus - A Beutaztató Utazási Irodák szemszögéból. OK-WORLD Travel Service, MUISZ - Beutaztató Bizottság, 2017. március 2-5. Konferencia elóadás. http:// slideplayer.hu/slide/12402892/, Letöltve: 2018. március 1. 